DOI: $10.1515 /$ LPTS-2015-0012

TECHNOLOGIES

\title{
INFLUENCE OF LIGHT INTENSITY AND TEMPERATURE ON CULTIVATION OF MICROALGAE Desmodesmus communis IN FLASKS AND LABORATORY-SCALE STIRRED TANK PHOTOBIOREACTOR
}

\author{
J. Vanags ${ }^{1}$, L. Kunga ${ }^{2}$, K. Dubencovs ${ }^{2}$, V. Galvanauskas ${ }^{2,3}$, O. Grīgs ${ }^{2}$
}

${ }^{1}$ Biotechnical Center, JSC, 27 Dzerbenes Str., LV-1006, Riga, LATVIA

${ }^{2}$ Institute of Wood Chemistry, Bioengineering laboratory,

27 Dzerbenes Str., LV-1006, Riga, LATVIA

${ }^{3}$ Kaunas University of Technology, Department of Automation, 50-162 Studentu Str., LT-51368, Kaunas, LITHUANIA

Optimization of the microalgae cultivation process and of the bioprocess in general traditionally starts with cultivation experiments in flasks. Then the scale-up follows, when the process from flasks is transferred into a laboratory-scale bioreactor, in which further experiments are performed before developing the process in a pilot-scale reactor. This research was done in order to scale-up the process from a 0.41 shake flask to a 4.01 laboratory-scale stirred-tank photobioreactor for the cultivation of Desmodesmus (D.) communis microalgae. First, the effect of variation in temperature $\left(21-29^{\circ} \mathrm{C}\right)$ and in light intensity $\left(200-600 \mu \mathrm{mol} \mathrm{m} \mathrm{m}^{-2} \mathrm{~s}^{-1}\right)$ was studied in the shake-flask experiments. It was shown that the best results (the maximum biomass concentration of $2.72 \mathrm{~g} \mathrm{l}^{-1}$ with a specific growth rate of $0.65 \mathrm{~g} \mathrm{~g}^{-1} \mathrm{~d}^{-1}$ ) can be achieved at the cultivation temperature and light intensity being $25{ }^{\circ} \mathrm{C}$ and $300 \mu \mathrm{mol} \mathrm{m} \mathrm{s}^{-1}$, respectively. At the same time, $D$. communis cultivation under the same conditions in stirred-tank photobioreactor resulted in average volumetric productivities of biomass due to the light limitation even when the light intensity was increased during the experiment (the maximum biomass productivity $0.25 \mathrm{~g} \mathrm{l}^{-1} \mathrm{~d}^{-1}$; the maximum biomass concentration $\left.1.78 \mathrm{~g} \mathrm{l}^{-1}\right)$.

Keywords: microalgae, Desmodesmus (D.) communis, shake flasks, photobioreactor, light, temperature

\section{INTRODUCTION}

Microalgae are widely used in different industries - pharmaceutical, cosmetic, in those dealing with pollution prevention and especially biofuels [1,2]. Ethanol and biodiesel - two of the most used biofuel types today [3, 4] - are primarily derived from plant sources (e.g., food crops). Nevertheless, because of the decreasing oil reserves an alternative lipid source is needed for biofuel production, and microalgae are one of them. Lipid compositions of microalgae and higher plants are not 
the same - there are some differences: for example, the relative proportion of polar lipids (triglycerides) is higher in microalgae, and also long-chain polyunsaturated fatty acids are produced there in more significant quantities. These aspects affect the efficiency of biodiesel synthesis and fuel properties [4]. Benefits of using microalgae instead of higher plants are that the former grow much faster, all cells are photosynthetic; nonseasonal harvesting, no direct competition with food market, etc. [5].

Because of this wide range of use, there is an active interest in microalgae large-scale cultivation. There are many types of photobioreactors in which various algal products can be obtained - e.g., bubble columns, tubular bioreactors, stirred tank reactors, etc. However, more and more new bioreactor concepts are developed $[6,7]$. Although open ponds are cheaper to build and maintain as compared with closed photobioreactors, the latter are often preferred because they can provide contaminant-free environment and make it possible to control the culture $\mathrm{pH}$, temperature, $\mathrm{CO}_{2}$ concentration in aeration gas, light intensity, and other culture variables $[1,8,9]$. Hence, the cultivation in closed photobioreactors gives a wider range of relevant products.

To make the performance of a new or improved process successful on the production scale, first, a good simulation of the cultivation conditions on the laboratory scale is to be done [6]. Bioprocess optimization traditionally starts with cultivation experiments in flasks. Afterwards, the scale-up is done, which means the process transfer from flasks to a laboratory-scale photobioreactor in which further experiments are performed prior to pilot plant studies [10]. The aim of the scaling-up is to obtain larger cell/product quantities at a larger scale with at least the same viability and quality of culture as obtained at a smaller scale $[11,12]$.

Analysis of the possibilities for intensifying the development of new products has shown that one of the main causes of delays in this research is insufficient compliance with scaling-up from flasks to a laboratory bioreactor. This means that often there is necessity for repeated studies in laboratory bioreactors of the technological cycles that are already developed in flasks. Some attempts have been reported to try scaling-up from flasks to stirred tanks. However, these reports mostly describe cultivation of bacteria and fungi. For example, during the Trichoderma harzianum 6-pentyl-a-pyrones (6PP) synthesis fermentation process it was found that 6PP synthesis starts sooner in photobioreactors than in flasks [13]. Bacillus subtilis purine nucleoside synthesis fermentation showed that the total amount of purine nucleosides produced in a bioreactor and flasks was almost the same, while the accumulation ratio of guanosine to total nucleosides was different [14]. Production of taxuyunnanine C (TC) from Taxus chinensis was significantly reduced when the process of cultivation was transferred from shake flasks to bioreactor [15]. The authors of the mentioned research works explain these differences by possible reaction of cells to the hydrodynamic stress caused by mixer.

Photobioreactors can be scaled-up by increasing such parameters as the length, diameter, height, or the number of compartments in the culture systems [6]. However, these scale-up strategies are poorly understood and challenging, since regardless of the bioreactor type - there are important issues that need to be taken into account when the vessel geometries change, e.g., effective provision of light, maintenance of optimal temperature, $\mathrm{CO}_{2}$ supply, mixing, and mass transfer in pho- 
tobioreactor $[6,16]$.

In microalgae mass production it is very important to achieve a sufficient supply of light in the culture due to the light being the only source of energy for growth of photoautotrophic microalgae [9, 17]. Thereby, the important criterion for achievement of the maximum algal productivity is the ratio between the illuminated surface area of the reactor and its volume (s/v), which determines the amount of light that enters the system per unit volume [7,9]. This means that the higher the surface-volume $(\mathrm{s} / \mathrm{v})$ ratio, the higher the cell concentration at which the reactor can be operated and the higher the volumetric productivity of the culture [7].

Mixing also has a remarkable effect on biomass production [18]. It prevents cells from settling, distributes nutrients, removes photosynthetically generated oxygen, ensures uniform distribution of light and temperature in the photobioreactor, etc. $[7,9,19]$. The type of device used to mix the culture is essential in the photobioreactor design, and along with the mixing intensity this should be chosen depending on characteristics of the specific microalgae culture to be cultivated $[7,10]$.

Microalgal biomass contains approximately $50 \%$ carbon by dry weight, which is typically derived from the most common carbon source for photosynthetic culture of microalgae - the carbon dioxide. Normally, it is supplied using continuous or intermittent injection. As the carbon is consumed, oxygen is ultimately produced by photolysis of water. By observing the changes in the culture's $\mathrm{pH}$ value, it is possible to follow the concentration of carbon dioxide $[16,20]$.

Our aim was to design a photobioreactor that can be easily and efficiently scaled up, enables easy control and variation of culture conditions (easily adjusted for any culture), has good mixing properties, and can be operated under sterile conditions. Although for the experiments the unicellular freshwater green algae D. communis were taken, the designed photobioreactor will also be employed for cultivation of Haematococcus pluvialis.

\section{MATERIALS AND METHODS}

\subsection{Microorganism and culture medium}

A novel strain of green algae was isolated from fresh water samples collected from the estuary zone of the Daugava river (Riga, Latvia) in August, 2008. This strain was identified as Desmodesmus communis named DCDA-3 (culture collection of the Latvian Institute of Aquatic Ecology).

The culture medium used was BG11, which consisted of $1.5 \mathrm{~g} \mathrm{l}^{-1} \mathrm{NaNO}_{3}, 0.04$ $\mathrm{g} \mathrm{l}^{-1} \mathrm{~K}_{2} \mathrm{HPO}_{4}, 0.075 \mathrm{~g} \mathrm{l}^{-1} \mathrm{MgSO}_{4} \cdot 7 \mathrm{H}_{2} \mathrm{O}, 0.006 \mathrm{~g} \mathrm{l}^{-1} \mathrm{Fe}\left(\mathrm{NH}_{4}\right)_{3}\left(\mathrm{C}_{6} \mathrm{H}_{5} \mathrm{O}_{7}\right)_{2}, 0.001 \mathrm{~g} \mathrm{l}^{-1}$ EDTANa ${ }_{2}, 0.006 \mathrm{~g} \mathrm{l}^{-1}$ citric acid, $0.02 \mathrm{~g} \mathrm{l}^{-1} \mathrm{Na}_{2} \mathrm{CO}_{3}, 0.036 \mathrm{~g} \mathrm{l}^{-1} \mathrm{CaCl}_{2} \cdot 2 \mathrm{H}_{2} \mathrm{O}, 0.001$ $\mathrm{g} \mathrm{l}^{-1}$ vitamin $\mathrm{B} 1$ and a trace element solution $-0.000040 \mathrm{~g} \mathrm{l}^{-1} \mathrm{CoCl}_{2} \cdot 6 \mathrm{H}_{2} \mathrm{O}, 0.00286$ $\mathrm{g} \mathrm{l}^{-1} \mathrm{H}_{3} \mathrm{BO}_{3}, 0.00181 \mathrm{~g} \mathrm{l}^{-1} \mathrm{MnCl}_{2} \cdot 4 \mathrm{H}_{2} \mathrm{O}, 0.000222 \mathrm{~g} \mathrm{l}^{-1} \mathrm{ZnSO}_{4} \cdot 7 \mathrm{H}_{2} \mathrm{O}, 0.00004 \mathrm{~g} \mathrm{l}^{-1}$ $\mathrm{Na}_{2} \mathrm{MoO}_{4} \cdot 2 \mathrm{H}_{2} \mathrm{O}, 0.000080 \mathrm{~g} \mathrm{l}^{-1} \mathrm{CuSO}_{4} \cdot 5 \mathrm{H}_{2} \mathrm{O}$. All media were autoclaved for sterilization at $120^{\circ} \mathrm{C}$ for $45 \mathrm{~min}$. The seeding culture was prepared using an exponentially growing culture. An appropriate volume of inoculum was chosen in order to obtain the optical density (OD) of 0.05 in the culture medium. 


\subsection{Experimental setup and cultivation conditions}

D. communis were grown in laboratory bottles and in a laboratory-scale stirred tank photobioreactor.

The parameters and the setup of laboratory bottle: $1.500 \mathrm{ml}$ DURAN ${ }^{\circledR}$ GLS $80^{\circledR}$ laboratory bottle (height $148 \mathrm{~mm}$, diameter $101 \mathrm{~mm}$ ), working volume $400 \mathrm{ml} ; 2$. Stirring - using a BioSan PSU-20i multifunctional orbital shaker; 3. Reflux condenser; 4. Cultivation temperature $\left(21,23,25,27,29^{\circ} \mathrm{C}\right)$ - provided by inserting the thermostat tubes into all bottles; 5 . Aeration - by bubbling air- $\mathrm{CO}_{2}$ mixture $(96: 4 \mathrm{v} / \mathrm{v} \%)$ continuously with a flow rate of $0.5 \mathrm{vvm}$ (gas volume per unit liquid culture volume and per minute); 6. Illumination provided by LED cases (various light/dark periods) made of $3 \mathrm{~m}$ long 3528SMD LED strips (9.6 W, $240 \mathrm{~lm}$, IP20 (white/cold), with 120 LEDs per meter). Various light intensities $-200,300,400,500,600 \mu \mathrm{mol} \mathrm{m}^{-2} \mathrm{~s}^{-1}$. All experiments were run in duplicates. Schematic diagram of the experimental setup is shown in previous report [21].

The parameters and the setup of stirred tank photobioreactor: 1 . Total volume 6.0 1, working volume 4.01 (height $340 \mathrm{~mm}$, diameter $195 \mathrm{~mm}$ ); 2. Reflux condenser; 3 . The upper magnetic stirrer drive equipped with a turbine-type impeller (100-300 rpm); 4. The $\mathrm{pH}$ and dissolved oxygen $\left(\mathrm{pO}_{2}\right)$ concentration were measured online (BIO-3 control unit; Riga, Latvia); 5. The thermoregulation $\left(25 \pm 1^{\circ} \mathrm{C}\right)$ was carried out by circulation of thermostated water through a jacket in the photobioreactor bottom; 6. Aeration - bubbling air- $\mathrm{CO}_{2}$ mixture $(96: 4 \mathrm{v} / \mathrm{v} \%)$ continuously with a flow rate of $0.25 \mathrm{vvm}$; 7. Illumination provided by putting a LED case around bioreactor. The case is made of $7 \mathrm{~m}$ long 5050SMD LED strips (14.6 W, $720 \mathrm{~lm}$, IP33, (white/cold), with 60 LEDs per meter). Schematic diagram is shown in Fig. 1.

The appropriate light intensity was adjusted using a LED dimmer (controller) and measured by a Li-250A Light Meter with a Li-190 quantum sensor ( $L i-C O R$ Inc., Lincoln, Nebraska, USA) at the surface of the vessels.

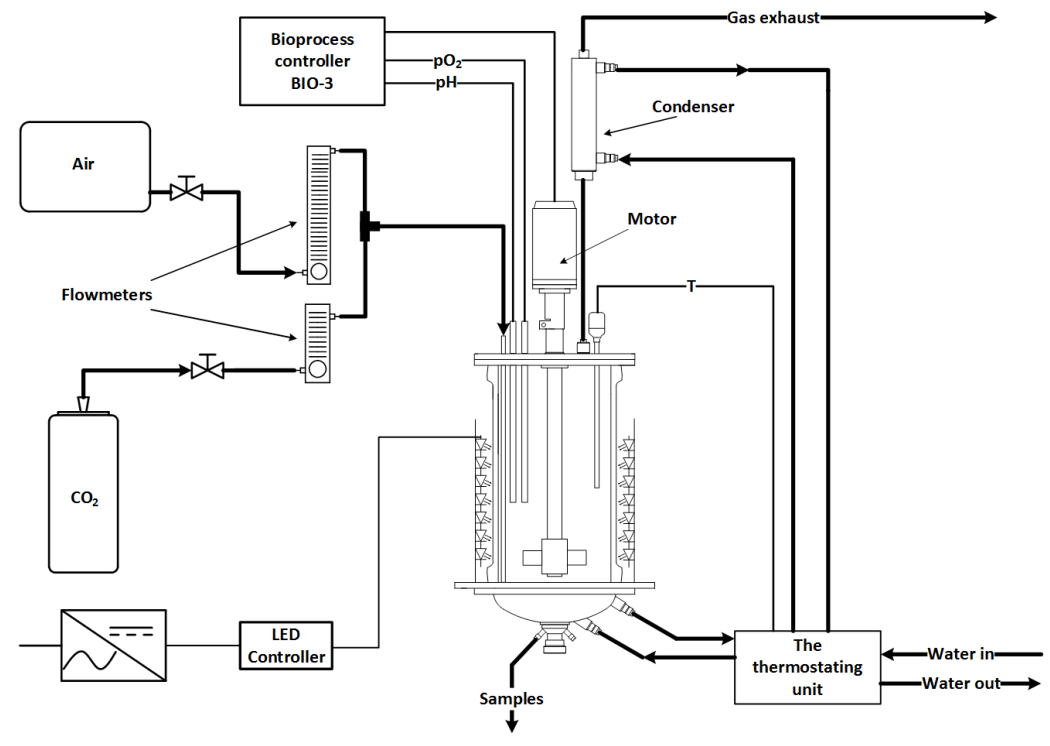

Fig. 1. Schematic diagram of the photobioreactor 


\subsection{Biomass production}

The culture was monitored by OD measurements at a wavelength of $550 \mathrm{~nm}$ using a Jenway 6300 spectrophotometer after appropriate dilution. Cell dry weight (CDW, $\mathrm{g} \mathrm{l}^{-1}$ ) of Desmodesmus communis could be correlated to the OD at $550 \mathrm{~nm}$ by the linear equation:

$$
C D W=0.45 \cdot O D .
$$

The biomass productivity was calculated from the variation in biomass concentration within the cultivation time using the equation:

$$
P=\frac{\left[X_{1}-X_{0}\right]}{\left[t_{1}-t_{0}\right]},
$$

where $\mathrm{X}_{0}$ is the biomass concentration $\left(\mathrm{g} \mathrm{l}^{-1}\right)$ in the day $\mathrm{t}_{0} ; \mathrm{X}_{1}$ - biomass concentration $\left(\mathrm{g}^{-1}\right)$ in the day $\mathrm{t}_{1}$.

The specific growth rate was determined as

$$
\mu=\frac{\ln X_{f}-\ln X_{i}}{t_{f}-t_{i}},
$$

where $\mathrm{X}_{\mathrm{f}}$ is the biomass concentration at the end of exponential growth phase (day $t_{\mathrm{f}}$ ); $\mathrm{X}_{\mathrm{i}}$ is the biomass concentration at the beginning of exponential growth phase (day $t_{\mathrm{i}}$ ).

\section{RESULTS AND DISCUSSION}

Generally used criteria for scaling-up the bioreactor are hydrodynamics and transfer properties, while the agitation power per reactor volume, the coefficient of volumetric mass transfer, the shear stress level and the time of mixing are parameters that are usually chosen to be kept constant. Furthermore, mixing in tubular or thinpanel photobioreactors is often insufficient and may cause problems like cell adhesion and growth on the vessel walls as well as accumulation of produced oxygen and heat inside the photobioreactor [22].

As mentioned earlier, in order to gain the best results by cultivating microalgae in a photobioreactor, first, the optimal conditions in flasks should be achieved; therefore, in previous work [21] the basal operating conditions of environmental factors were determined. The previous studies have shown that the aeration by air- $\mathrm{CO}_{2}$ mixture $96: 4 \mathrm{v} / \mathrm{v} \%$ which was continuously supplied at a flow rate of $0.05 \mathrm{vvm}$ has no limitation effect on the algae growth rate when mixing (by shaker) is provided. Mixing in the photobioreactor constructed during this research was provided by a mixer with axial flow impeller and aeration of $96: 4 \mathrm{v} / \mathrm{v} \%$ air- $\mathrm{CO}_{2}$ mixture. Therefore, the following assumption has been made - the algae growth kinetics is not limited by the mixing and hydrodynamics, with no inhibition by $\mathrm{O}_{2}$ concentration as well as no limitation and inhibition by $\mathrm{CO}_{2}$ observed. 
In this research, emphasis is made on providing for the culture sufficient light supply and optimal temperature, since these environmental factors are among the prime ones affecting the microalgae growth $[23,24]$.

\subsection{The effect of temperature on microalgae cultivation}

Temperature influences the algae growth rate, cell size, biochemical composition, and nutrient requirements. The culture growth rate increases until the strain's optimal cultivation temperature is reached, after which a significant decrease in the growth rate can be observed. If the temperature is higher than the optimum, it reduces the synthesis of proteins and decreases the growth rates. Cultivation at optimal temperature provides the minimum cell size as well as efficient carbon and nitrogen utilization and reduces the risk of photoinhibition [25].

As mentioned above, in the laboratory-scale photobioreactor designed during this research the thermoregulation $\left(25 \pm 1{ }^{\circ} \mathrm{C}\right)$ is carried out by circulation of thermostated water through a jacket in the photobioreactor bottom, which means that there could be a temperature gradient between the top and bottom sides of reactor when scaling-up is done. Therefore, series of experiments were run in laboratory bottles under different temperatures $\left(21,23,25,27\right.$, and $\left.29^{\circ} \mathrm{C}\right)$ in order to determine the optimal temperature and the temperature influence on the algae growth rate and productivity for D. Communis cultivation. The results obtained are shown in Fig. 2 and Table 1.

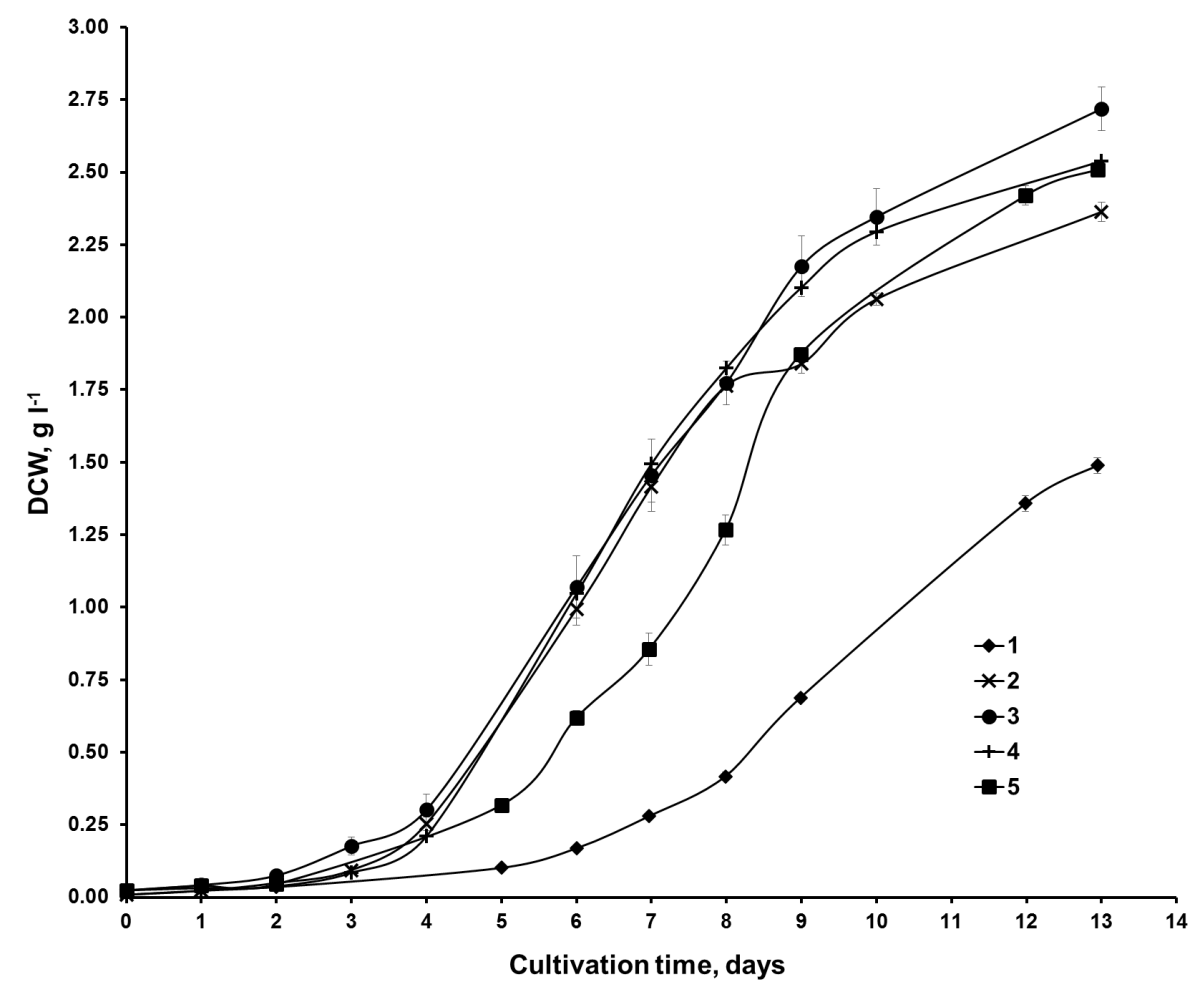

Fig. 2. Effect of different temperatures: $21^{\circ} \mathrm{C}(1), 23^{\circ} \mathrm{C}(2), 25^{\circ} \mathrm{C}(3), 27^{\circ} \mathrm{C}(4)$, and $29^{\circ} \mathrm{C}(5)$, on the algae biomass growth. 
Microalgae growth rate, maximum biomass productivity, and maximum biomass concentration at different temperatures

$\left(\mathrm{t}\right.$ - temperature; $\mu$ - specific growth rate; $\mathrm{P}_{\max }$ - maximum biomass productivity;

$\mathrm{X}_{\max }-$ maximum biomass concentration).

\begin{tabular}{|c|c|c|c|}
\hline${ }^{\mathbf{t}} \mathrm{C}$ & $\begin{array}{c}\mu, \\
\mathrm{g} \mathrm{g}^{-1} \mathbf{d}^{-1}\end{array}$ & $\underset{\mathrm{g} \mathrm{l}^{\mathbf{l a x}^{-1} \mathbf{d}^{-1}}}{\mathbf{P}}$ & $\begin{array}{l}\mathrm{X}_{\max }, \\
\mathrm{g} \mathrm{l}^{-1}\end{array}$ \\
\hline 21 & 0.51 & 0.60 & 2.5 \\
\hline 23 & 0.65 & 0.44 & 2.59 \\
\hline 25 & 0.65 & 0.40 & 2.72 \\
\hline 27 & 0.64 & 0.42 & 2.3 \\
\hline 29 & 0.36 & 0.27 & 1.36 \\
\hline
\end{tabular}

As shown in Fig. 2 and Table 1, algae cultivation in the temperature range of $23-27^{\circ} \mathrm{C}$ practically does not affect the algae growth rate $\left(0.64-0.65 \mathrm{~g} \mathrm{~g}^{-1} \mathrm{~d}^{-1}\right)$, the productivity $\left(0.40-0.44 \mathrm{~g} \mathrm{l}^{-1} \mathrm{~d}^{-1}\right)$, and the maximum biomass concentration 2.3-2.72 $\left.\mathrm{g} \mathrm{l}^{-1}\right)$. At temperatures $<23{ }^{\circ} \mathrm{C}$ and $>27{ }^{\circ} \mathrm{C}$ the specific growth rate is significantly lower, 0.51 and $0.36 \mathrm{~g} \mathrm{~g}^{-1} \mathrm{~d}^{-1}$, respectively. This shows that the temperature of $21{ }^{\circ} \mathrm{C}$ is insufficient for $D$. communis cultivation, while that of $29^{\circ} \mathrm{C}$ is too high. Meanwhile, the results obtained at 23,25 and $27^{\circ} \mathrm{C}$ are very close, so it can be concluded that the optimal temperature for cultivation of $D$. communis is $25 \pm 2{ }^{\circ} \mathrm{C}$, which means that the temperature gradient in photobioreactor during cultivation of this particular microalgae strain can reach 4 degrees (from 23 to $27^{\circ} \mathrm{C}$ ).

\subsection{The effect of light intensity on microalgae cultivation}

Microalgae use light as a source of energy for synthesizing the cell protoplasm, and have the light saturation limit, i.e. the growth rate is maximum at the saturation intensity of light and decreases when its intensity increases or decreases $[24,25]$.

Photoadaptation process changes the algae cell properties according to the availability of light and photosynthesis efficiency. Adaptation can occur through changes in the types and quantities of pigments, in the growth rate, dark respiration rate, the availability of essential fatty acids and other mechanisms [25]. Increase in the light intensity above the saturation limit acts dissimilarly on different algae strains; for example, when Haematococcus pluvialis are exposed to high-intensity light, they start to produce astaxanthin because of the induced stress [26]. For other microalgae, increase in the light intensity causes photoinhibition because of disruption of the chloroplast lamellae growth and inactivation of the enzymes involved in the carbon dioxide fixation [25]. It has to be taken into account that the intensity of light should be increased so that it penetrates through the culture if the microalgae are cultivated at higher depth and cell concentrations [24].

In previous study [21], the effect of three different light intensities $(100,200$, and $300 \mu \mathrm{mol} \mathrm{m} \mathrm{m}^{-2} \mathrm{~s}^{-1}$ ) on the algae growth was evaluated, and it was concluded that in this range the best is $300 \mu \mathrm{mol} \mathrm{m} \mathrm{m}^{-2} \mathrm{~s}^{-1}$. In this study, the range of light intensities was extended $\left(200,300,400,500\right.$, and $\left.600 \mu \mathrm{mol} \mathrm{m}^{-2} \mathrm{~s}^{-1}\right)$ in order to determine the effect of even higher light supply (see Fig. 3); the results for microalgae growth rate, 
biomass productivity, and the maximum biomass concentration under these conditions are given in Table 2.

Figure 3 and Table 2 show that the exponential growth phase lasts approx. four days at the biomass concentration of $0.3 \mathrm{~g} \mathrm{l}^{-1}$, and is followed by a linear growth phase due to progressive light limitation. At the start of the experiment, the highest growth rate was obtained at the light intensity of $200 \mu \mathrm{mol} \mathrm{m} \mathrm{m}^{-2}$, while the biomass productivity $\left(0.34 \mathrm{~g} \mathrm{l}^{-1} \mathrm{~d}^{-1}\right)$ and the maximum biomass concentration $\left(2.1 \mathrm{~g}^{-1}\right)$ at this intensity were the lowest, indicating strong light limitation. The algae cultivation at the light intensity of $300-500 \mu \mathrm{mol} \mathrm{m}^{-2} \mathrm{~s}^{-1}$ has a very limited effect on the productivity (0.40-0.42 $\left.\mathrm{g} \mathrm{l}^{-1} \mathrm{~d}^{-1}\right)$ and the maximum biomass concentration (2.54-2.72 $\left.\mathrm{g} \mathrm{l}^{-1}\right)$, with only the specific growth rate changing $\left(0.59-0.65 \mathrm{~g} \mathrm{~g}^{-1} \mathrm{~d}^{-1}\right)$. A long-lasting photoadaptation was observed when microalgae were cultivated at $600 \mu \mathrm{mol} \mathrm{m} \mathrm{m}^{-2} \mathrm{~s}^{-1}$, which also led to the lowest specific growth rate $\left(0.22 \mathrm{~g} \mathrm{~g}^{-1} \mathrm{~d}^{-1}\right)$. Although the maximum biomass concentration obtained at $600 \mu \mathrm{mol} \mathrm{m} \mathrm{m}^{-2} \mathrm{~s}^{-1}$ was the second highest, undesirable pigment loss at photo-oxidation was observed in the culture, which means that such light intensity is not appropriate.

According to the results obtained, it can be concluded that the optimal light intensity for D. communis cultivation is $300 \mu \mathrm{mol} \mathrm{m} \mathrm{m}^{-2} \mathrm{~s}^{-1}$, which makes it possible to gain the maximum biomass concentration $\left(2.72 \mathrm{~g}^{-1}\right)$, with the growth rate being sufficiently high.

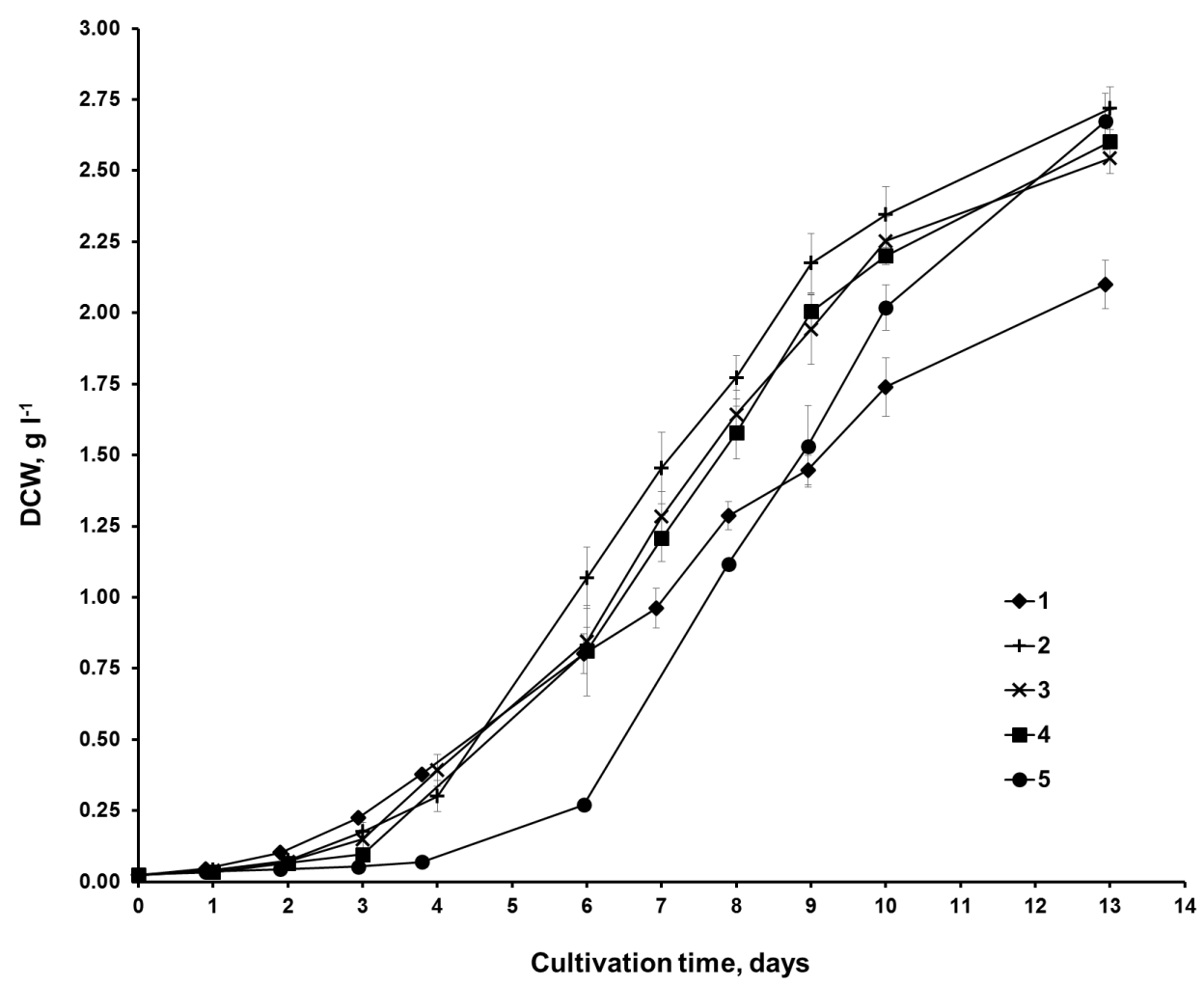

Fig. 3. Effect of different light intensities: $200 \mu \mathrm{mol} \mathrm{m}^{2} \mathrm{~s}^{-1}(1)$, $300 \mu \mathrm{mol} \mathrm{m} \mathrm{s}^{-1}(2), 400 \mu \mathrm{mol} \mathrm{m} \mathrm{s}^{-1}(3), 500 \mu \mathrm{mol} \mathrm{m}^{2} \mathrm{~s}^{-1}$ (4) and $600 \mu \mathrm{mol} \mathrm{m} \mathrm{m}^{2} \mathrm{~s}^{-1}(5)$, on the algae biomass growth. 
Microalgae growth rate, maximum biomass productivity, and maximum biomass concentration at different light intensities.

$\mathrm{I}$ - light intensity; $\mu$ - specific growth rate; $\mathrm{P}_{\max }$ - maximum biomass productivity;

$\mathrm{X}_{\max }$ - maximum biomass concentration.

\begin{tabular}{|c|c|c|c|}
\hline $\begin{array}{c}\mathrm{I}, \\
\mu \mathrm{mol} \mathrm{m}^{-2} \mathrm{~s}^{-1}\end{array}$ & $\begin{array}{c}\mu, \\
\mathrm{g} \mathrm{g}^{-1} d^{-1}\end{array}$ & $\begin{array}{l}P_{\text {max }} \\
\text { g l-1 }^{-1} d^{-1}\end{array}$ & $\begin{array}{c}X_{\max }, \\
\mathrm{g} \mathrm{l}^{-1}\end{array}$ \\
\hline 200 & 0.74 & 0.34 & 2.10 \\
\hline 300 & 0.65 & 0.4 & 2.72 \\
\hline 400 & 0.60 & 0.41 & 2.54 \\
\hline 500 & 0.59 & 0.42 & 2.60 \\
\hline 600 & 0.22 & 0.47 & 2.67 \\
\hline
\end{tabular}

\subsection{Cultivation of microalgae in photobioreactor.}

When the algae cultivation is performed in photobioreactor, it is difficult to gain the same productivity and biomass concentration as in flasks. Usually, this is because of the light and mass transfer limitation. In literature it is reported that the maximum concentration of Scenedesmus quadricauda cultivated in a cylindrical glass photobioreactor $\left(300 \mu \mathrm{mol} \mathrm{m} \mathrm{s}^{-1}, 25 \pm 1^{\circ} \mathrm{C}, \mathrm{CO}_{2}-6 \mathrm{v} / \mathrm{v} \%\right)$ is $2.301 \mathrm{~g} \mathrm{l}^{-1}$ [27]. Meanwhile, in this research Desmodesmus communis was cultivated in a stirred tank photobioreactor $\left(300 \mu \mathrm{mol} \mathrm{m}^{2} \mathrm{~s}^{-1}, 25 \pm 1{ }^{\circ} \mathrm{C}, \mathrm{CO}_{2}-4 \mathrm{v} / \mathrm{v} \%\right)$ with the maximum biomass concentration reached $1.46 \mathrm{~g} \mathrm{l}^{-1}$, while the specific growth rate and the maximum productivity $-0.49 \mathrm{~g} \mathrm{~g}^{-1} \mathrm{~d}^{-1}$ and $0.18 \mathrm{~g} \mathrm{l}^{-1} \mathrm{~d}^{-1}$, respectively. These results are significantly lower than the ones obtained in flasks under the same conditions. Such a difference can be explained by strong light limitation. The results are shown in Fig. 4.

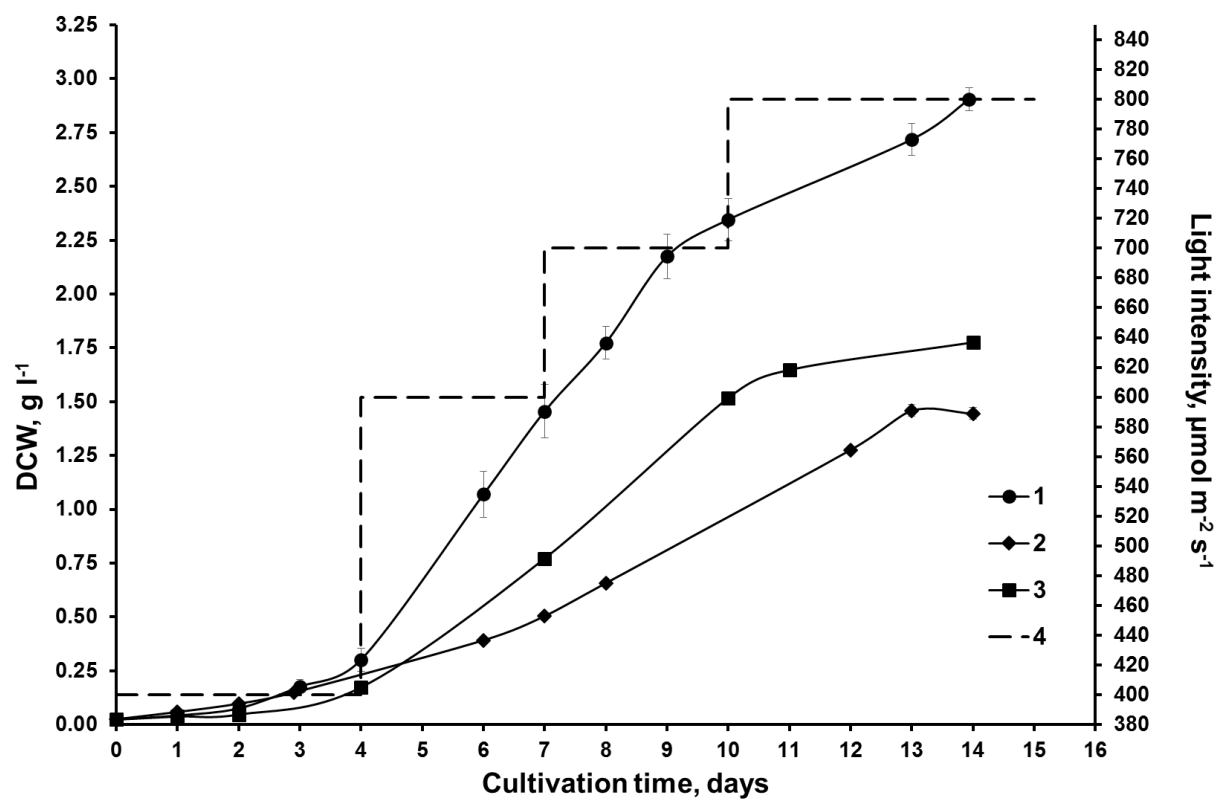

Fig. 4. Comparison of D. communis cultivation results obtained in 0.41 laboratory bottle (1) and 4.01 laboratory-scale photobioreactor $(2,3) ;(4)$ - the light intensity profile for experiment 3. 
In order to yield a higher biomass concentration, to raise the growth rate, and to minimize the limitation effect of light shading in high-density cultures, another experiment in the photobioreactor was performed. In this experiment, the light intensity was increasing with the cultivation time (Fig. 4, curve 4), which resulted in the increase in the maximum biomass productivity and concentration of $0.25 \mathrm{~g} \mathrm{l}^{-1} \mathrm{~d}^{-1}$ and $1.78 \mathrm{~g} \mathrm{l}^{-1}$,respectively. However, as seen in Fig. 4, these results still are lower than the ones obtained in flasks.

At the end of the experiment, algae cells were examined under microscope, and many damaged cells were observed. Cell damage can be explained by the shear stress due to operation of the turbine-type impeller used in the photobioreactor. Along with the light limitation, this can be one of the reasons why in the photobioreactor the algae biomass growth rate was lower than in flasks.

\section{CONCLUSIONS}

The use of microalgae $D$. communis for studying the influence of temperature and light intensity on microalgae biomass growth in shake flasks and stirred tank photobioreactor has given good results. It was found that at the algae cultivation in a shake flask in the temperature range of $23-27{ }^{\circ} \mathrm{C}$ there was a very limited effect on the algae growth rate $\left(0.64-0.65 \mathrm{~g} \mathrm{~g}^{-1} \mathrm{~d}^{-1}\right)$, the productivity $\left(0.40-0.44 \mathrm{~g}^{-1} \mathrm{~d}^{-1}\right)$, and the maximum biomass concentration (2.3-2.72 $\left.\mathrm{g} \mathrm{l}^{-1}\right)$. Meanwhile, the value of $300 \mu \mathrm{mol}$ $\mathrm{m}^{-2} \mathrm{~s}^{-1}$ was determined to be the optimal light intensity giving the maximum biomass concentration of $2.72 \mathrm{~g} \mathrm{l}^{-1}$ with the growth rate of $0.65 \mathrm{~g} \mathrm{~g}^{-1} \mathrm{~d}^{-1}$. Microalgae cultivation in the photobioreactor operated in the batch mode was found to have worse average volumetric productivities of biomass as compared with the best results attained in the shake flask experiments. In order to decrease the number of damaged cells and increase the biomass yield from photobioreactor, in further experiments another type impeller is to be used, e.g., a shear-sensitive agitator (marine impeller) with a blade angle of 30 degrees.

\section{ACKNOWLEDGEMENTS}

The financial support from the ERAF within the scientific research project "Research on high-quality product yield using microalgae cultivation in laboratory and pilot-scale bioreactors" (ref. no. 2013/0041/2DP/2.1.1.1.0/13/APIA/VIAA/025) is gratefully acknowledged.

\section{REFERENCES}

1. Rosenberg, J. N., Oyler, G. A., Wilkinson, L., \& Betenbaugh, M. J. (2008). A green light for engineered algae: redirecting metabolism to fuel a biotechnology revolution. Current Opinion in Biotechnology. 19 (5), 430-436.

2. Mata, T.M., Martins, A.A., \& Caetano, N.S. (2010) Microalgae for biodiesel production and other applications: a review. Renewable and Sustainable Energy Reviews, 1 (14), 217-232. 
3. Greenwell, H.C., Laurens, L.M.L., Shields, R.J., Lovitt, R.W., \& Flynn, K.J. (2010). Placing microalgae on the biofuels priority list: a review of the technological challenges. Journal of the Royal Society Interface, 7, $703-726$.

4. Yu, W. L., Ansari, W., Schoepp, N. G., Hannon, M. J., Mayfield, S. P., \& Burkart, M. D. (2011). Modifications of the metabolic pathways of lipid and triacylglycerol production in microalgae. Microb. Cell Fact., 10, 91.

5. Subramanian, S., Barry, A. N., Pieris, S., \& Sayre, R. T. (2013). Comparative energetics and kinetics of autotrophic lipid and starch metabolism in chlorophytic microalgae: implications for biomass and biofuel production. Biotechnology for biofuels, 6 (1), 150.

6. Oosterhuis, N.M.G. (1984). Scale-up of Bioreactors: A Scale-down Approach. Ph.D. Thesis Delft University of Technology, Huisdrukkerij Suiker Unie.

7. Sherif, S. A., Goswami, D. Y., Stefanakos, E. L., \& Steinfeld, A. (2014). Handbook of Hydrogen Energy. Boca Raton, FL, USA: CRC Press.

8. Scott, S.A., Davey, M.P., Dennis, J.S. Horst, I., Howe, C.J., \& Lea-Smith, D.J. (2010). Biodiesel from algae: challenges and prospects. Current Opinion in Biotechnology. 3 (21), 277-286.

9. Kroumov, A., Gacheva, G., Iliev, I., Alexandrov, S., Pilarski, P., \& Petkov, G. (2013). Analysis of $\mathrm{S}_{\mathrm{f}} / \mathrm{V}$ ratio of photobioreactors linked with algal physiology. Genetics and Plant Physiology, 3 (1-2), 55-64.

10. Garcia-Ochoa, F., \& Gomez, E. (2009). Bioreactor scale-up and oxygen transfer rate in microbial processes: an overview. Biotechnology advances, 27 (2), 153-176.

11. Takors, R. (2012). Scale-up of microbial processes: impacts, tools and open questions. Journal of Biotechnology, 160 (1), 3-9.

12. Trujillo-Roldán, M. A., Valdez-Cruz, N. A., Gonzalez-Monterrubio, C. F., AcevedoSánchez, E. V., Martínez-Salinas, C., García-Cabrera, R. I., Gamboa-Suasnavart, R. A., Marín-Palacio, L. D., Villegas J., \& Blancas-Cabrera, A. (2013). Scale-up from shake flasks to pilot-scale production of the plant growth-promoting bacterium Azospirillum brasilense for preparing a liquid inoculant formulation. Applied Microbiology and Biotechnology, 97 (22), 9665-9674.

13. Rocha-Valadez, J. A., Estrada, M., Galindo, E., \& Serrano-Carreón, L. (2006). From shake flasks to stirred fermentors: Scale-up of an extractive fermentation process for 6-pentyl- $\alpha$-pyrone production by Trichoderma harzianum using volumetric power input. Process Biochemistry, 41 (6), 1347-1352.

14. Sumino, Y., Sonoi, K., \& Doi, M. (1993). Scale-up of purine nucleoside fermentation from a shaking flask to a stirred-tank fermentor. Applied microbiology and biotechnology, 38 (5), 581-585.

15. Pan, Z. W., Wang, H. Q., \& Zhong, J. J. (2000). Scale-up study on suspension cultures of Taxus chinensis cells for production of taxane diterpene. Enzyme and Microbial Technology, 27 (9), 714-723.

16. Grima, E. M., Fernández, F. A., Camacho, F. G., \& Chisti, Y. (1999). Photobioreactors: light regime, mass transfer, and scaleup. Journal of biotechnology, 70 (1), 231-247.

17. Ogbonna, J. C., Soejima, T., \& Tanaka, H. (1998). Development of efficient large-scale photobioreactors. In: Zaborsky OR (ed.), BioHydrogen. Plenum Press, New York \& London, pp. 329-343.

18. Ugwu, C.U., Aoyagi, H., \& Uchiyama, H. (2008). Photobioreactors for mass cultivation of algae. Bioresource Technology, 10 (99), 4021-4028.

19. Kunjapur, A.M., \& Eldridge, R.B. (2010). Photobioreactor design for commercial biofuel production from microalgae. Industrial \& Engineering Chemistry Research, 8 (49), 3516-3526. 
20. Chisti, Y. (2007) Biodiesel from microalgae. Biotechnology Advances, 3(25), 294-306.

21. Vanags, J., Kunga, L., Dubencovs, K., Galvanauskas, V., Balode, M., \& Grīgs, O. (2015). The effect of shaking, $\mathrm{CO} 2$ concentration and light intensity on biomass growth of green microalgae Desmodesmus communis. Environmental Research, Engineering and Management. 70 (4), 73-79.

22. Tredici, M. R., \& Materassi, R. (1992). From open ponds to vertical alveolar panels: the Italian experience in the development of reactors for the mass cultivation of phototrophic microorganisms. Journal of Applied Phycology. 4 (3), 221-231.

23. Siver, P. A. (1983). A new thermal gradient device for culturing algae. British Phycological Journal. 18 (2), 159-164.

24. Wahidin, S., Idris, A., \& Shaleh, S. R. M. (2013). The influence of light intensity and photoperiod on the growth and lipid content of microalgae Nannochloropsis sp. Bioresource technology, 129, 7-11.

25. Juneja, A., Ceballos, R. M., \& Murthy, G. S. (2013). Effects of Environmental Factors and Nutrient Availability on the Biochemical Composition of Algae for Biofuels Production: A Review. Energies, 6 (9), 4607-4638.

26. Dragoş, N., Bercea, V., Bica, A., Drugă, B., Nicoară, A., \& Coman, C. (2010). Astaxanthin production from a new strain of Haematococcus pluvialis grown in batch culture. Annals of the Romanian society for cell biology, 15 (2), 353-361.

27. Xiao, R., Chen, R., Zhang, H. Y., \& Li, H. (2011). Microalgae Scenedesmus quadricauda grown in digested wastewater for simultaneous $\mathrm{CO}_{2}$ fixation and nutrient removal. Journal of Biobased Materials and Bioenergy, 5 (2), 234-240.

\title{
GAISMAS INTENSITĀTES UN TEMPERATŪRAS IETEKME UZ MIKROALGGU DESMODESMUS COMMUNIS KULTIVĀCIJU KOLBĀS UN LABORATORIJAS MĒROGA FOTOBIOREAKTORĀ
}

\author{
J. Vanags, L. Kunga, K. Dubencovs, \\ V. Galvanauskas, O. Grīgs
}

Kopsavilkums

Mikroaļgu kultivēšanas procesa optimizēšana parasti sākas ar kultivēšanas eksperimentiem kolbās. Tālāk seko procesa pārnese uz laboratorijas mēroga fotobioreaktoru, kurā tiek veikti tālāki eksperimenti, pirms tiek izveidots pilota mēroga reaktors. Šis pētîjums tika veikts ar mērksi, pārnest Desmodesmus communis kultivēšanas procesu no 0.41 kolbas uz 4.01 laboratorijas fotobioreaktoru. Vispirms tika pētīta dažādu temperatūru $\left(21-29^{\circ} \mathrm{C}\right)$ un gaismas intensitātes $\left(200-600 \mu \mathrm{mol} \mathrm{m} \mathrm{s}^{-2} \mathrm{~s}^{-1}\right)$ ietekme uz aļgu biomasu veicot eksperimentus kolbās. Labākie rezultāti (maksimālā biomasas koncentrācija $2.72 \mathrm{~g} \mathrm{l}^{-1}$; īpatnējais augšanas ātrums $0.65 \mathrm{~g} \mathrm{~g}^{-1} \mathrm{~d}^{-1}$ ) sasniegti, kad kultivācijas temperatūra ir $25^{\circ} \mathrm{C}$ un gaismas intensitāte $-300 \mu \mathrm{mol} \mathrm{m} \mathrm{m}^{-1}$. Savukārt D. communis kultivācija fotobioreaktorā pie tādiem pašiem apstākḷiem deva vidējus biomasas produktivitātes rezultātus gaismas limitēšanas dēḷ arī tad, kad gaismas intensitāte tika palielināta eksperimenta laikā (maksimālā biomasas produktivitāte $0.25 \mathrm{~g} \mathrm{l}^{-1} \mathrm{~d}^{-1}$; maksimālā biomasas koncentrācija - $1.78 \mathrm{~g} \mathrm{l}^{-1}$ ).

09.02.2015. 